\title{
INFORMATION FLOW SETTINGS IN BUILDING REHABILITATION
}

\author{
S. Elwazani ${ }^{a}$, S. Gandikota ${ }^{a}$ \\ ${ }^{a}$ Department of Architecture and Environmental Design, Bowling Green State University, \\ 103 Park Avenue, Bowling Green, OH 43403- selwaza@bgsu.edu
}

KEY WORDS: Information Flow, Rehabilitation, Information Settings, Building Significance, Building Integrity and Authenticity, Historic Context

\begin{abstract}
:
Apart from the usual field technical survey information for establishing the building configurations and fabric conditions, information flow for a rehabilitation project begins earlier with the need for authenticating the building as a significant heritage item and ends subsequently with validating the rehabilitation of the building. These three genres of the information are recognized under three information settings. This study investigates the first, the setting associated with authenticating the significance of the building. The discussion is structured around the process of evaluating building significance for the purpose of listing the building on the National Register of Historic Places (NRHP) and, accordingly, recognizes the NRHP framework for nominating properties to the Register. With due consideration to the concomitant information and documentation along the nomination process, and with the "historic context" as a core significance assessment strategy, the study aims at: a) explaining the configuration of the historic context; b) clarifying the role of the building itself in developing the historic context; and, c) identifying the attributes of information flow. The study arrived at the following conclusions. Investigating "the information associated with authenticating the significance of the building," the focus of this study, as an information setting of a spectrum of three helps define the global information flow in building rehabilitation. Steeped in research, the historic context configuration and development steps regulate the information flow of this setting. The knowledge and dexterity of the researcher in configuring and developing the historic context enhances the clarity and characteristics of information flow.
\end{abstract}

\section{OVERVIEW}

\subsection{General}

The information acquired, reduced, and presented throughout a rehabilitation project are handled by multiple parties to serve distinct purposes. The information usually obtained through the field surveys involving measured recording and fabric conditions assessment to establish the building configurations - the information the professionals of CIPA are familiar with-is only one genre of information needed to satisfy the requirements of a viable rehabilitation project. Another genre of information is associated with the very definition of a heritage property, that is, the information needed to authenticate that the property is "significant" in the first place. The activity to secure this information typically takes place early on in the rehabilitation project and, fittingly, before delving into the technical field survey activity. A third genre of information is associated with the execution of the rehabilitation in compliance with the established rehabilitation standards.

This study recognizes the three genres of information as belonging to "settings". A setting combines circumstances that set up the need and flow for the commensurate information, the drivers and frame of action for information collection and processing. In a global view on the flow of information throughout the rehabilitation undertaking as practiced in the United States, this recognition renders three broad information settings fitting together as shown in Figure 1. Table 1 lists the three settings with their underpinning premises. For obvious reasons, the investigation will refer considerably to the literature of the U.S. National Register of Historic Places, especially the material on researching historic properties, assessing cultural significance, and structuring historic contexts. The terms building and property will be used interchangeably.

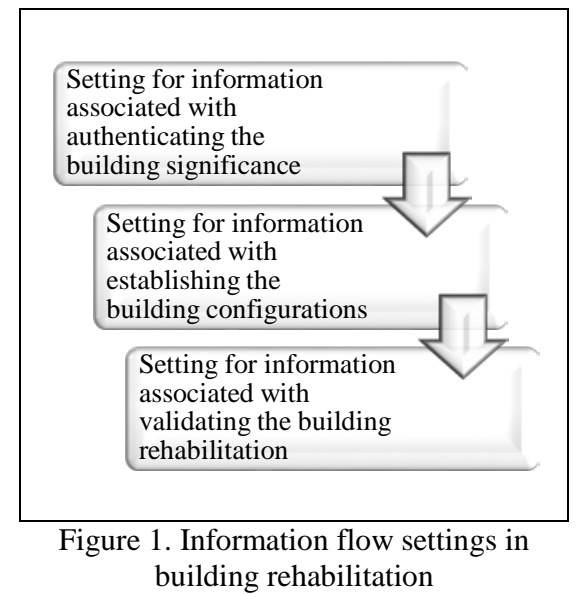




\begin{tabular}{l|l}
\hline \hline Setting & Premise \\
\hline \hline $\begin{array}{l}\text { 1. Setting for information } \\
\text { associated with } \\
\text { authenticating the } \\
\text { building significance }\end{array}$ & $\begin{array}{l}\text { The } \\
\text { possesses a historic } \\
\text { "significance” }\end{array}$ \\
\hline $\begin{array}{l}\text { 2. Setting for information } \\
\text { associated with } \\
\text { establishing the building } \\
\text { configurations }\end{array}$ & $\begin{array}{l}\text { Rehabilitation } \\
\text { operations are based } \\
\text { on the current "as is" } \\
\text { condition information }\end{array}$ \\
\hline $\begin{array}{l}\text { 3. Setting for information } \\
\text { associated with validating } \\
\text { the building rehabilitation }\end{array}$ & $\begin{array}{l}\text { Acceptable } \\
\text { rehabilitation meets } \\
\text { the Secretary of the } \\
\text { Interior Standards }\end{array}$ \\
\hline
\end{tabular}

Table 1. The information settings and their premises

\subsection{The Study Scope and Aims}

This study singles out and investigates the first information setting, the one associated with authenticating the significance of the building. The discussion is structured around the process of evaluating building significance for the purpose of listing the building on the National Register of Historic Places (NRHP) and, accordingly, the discussion recognizes the framework for nominating properties to the Register. With due consideration to parallel information and documentation along the nomination process, and with the "historic context” (HC) as a significance assessment strategy, the study aims at: a) explaining the configuration of the historic context; b) clarifying the role of the building itself in developing the historic context; and, c) identifying the attributes of information flow.

\subsection{Building Significance in the Rehabilitation Process}

Significance underlies the principles, standards, and guidelines for the heritage conservation field. According to the National Register of Historic Places (NRHP), a significant property "must represent a significant part of the history, architecture, archeology, engineering, or culture of an area, and it must have the characteristics that make it a good representative of properties associated with that aspect of the past” (NRB 15, p. 7).

Building rehabilitation builds on the building significance. Rehabilitation, or any other type of intervention for that matter, starts with steps to corroborate the building significance, a condition without which the building may not be slated for "certified" rehabilitation. Significance drives the inevitable and parallel data acquisition and reduction early on in the rehabilitation project to substantiate one or more of the following NRHP areas of criteria: a) events infusing patterns of history, b) lives of renowned individuals, c) ingenuity in design and construction, and d) adding information to history or prehistory (NRB 15, p. 11) (Figure 2).

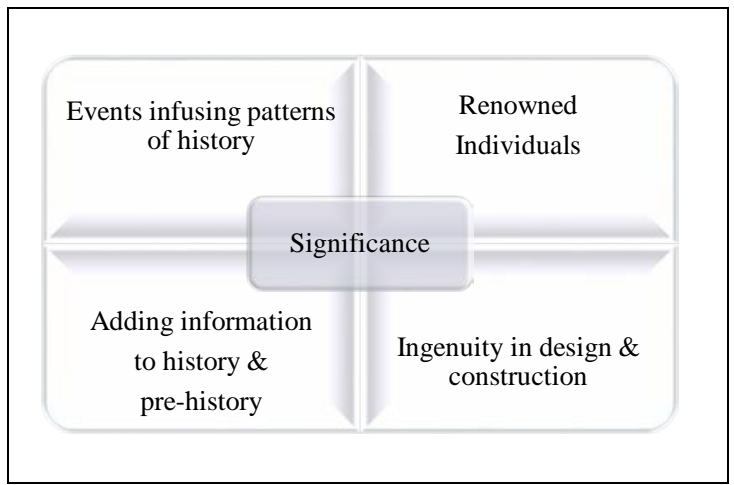

Figure 2. NRHP significance criteria that drive information acquisition and reduction

The types of information and professional expertise demanded to establish significance within the study information setting can be inferred from the steps for: first, configuring the historic context with which the property is associated (steps 1 and 2- Figure 3) and, second, corroborating that the building itself supports the historic context (steps 3, 4, and 5-Figure 3).

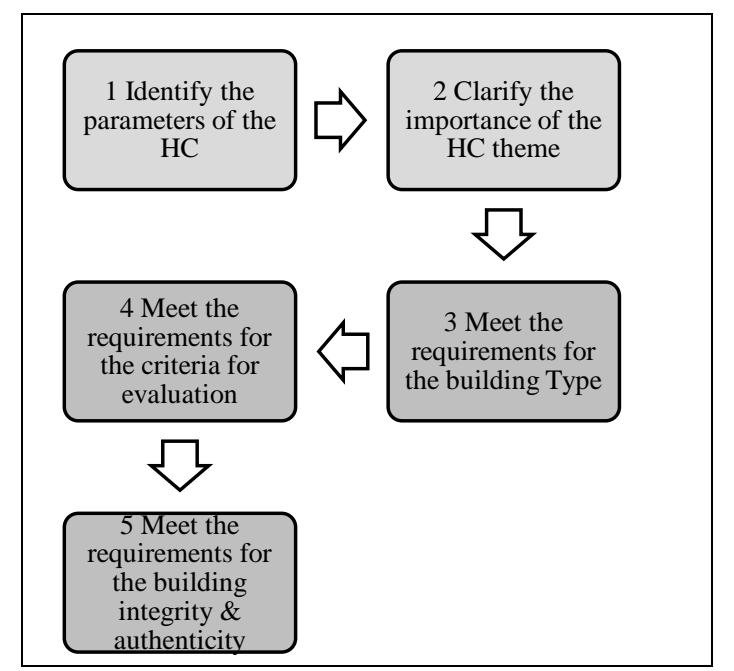

Figure 3. Significance assessment steps with their implication on information flow

\section{THE CONFIGURATION OF A HISTORIC CONTEXT}

\subsection{The Parameters of the Historic Context}

Historic contexts are "those patterns or trends in history by which a specific occurrence, property, or site is understood and its meaning (and ultimately its significance) within history or prehistory is made clear" (NRB 15, p. 7). This subsection defines the three parameters around which a historic context of the property is configured and describes the applicability of historic contexts in general (Figure 4). The three parameters are place, time, and theme. The place can be the geographic area where the building is located; the time comprises the period during which the building significance accrued; the theme holds the reasons (events, trends) upon which significance is based. 


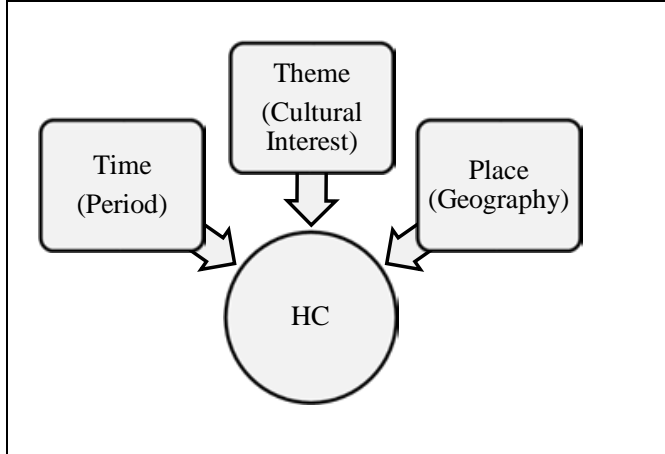

Figure 4. Parameters of the Historic Context

Historic context applies to heritage properties in general including buildings (emphasized in this study), historic districts, sites, structures, and objects. The historic context method also applies to themes associated with historic properties at the level of town, city, region, the State or the nation. In case the building is a part of a historic district, the significance of the building can be understood within the framework of the historic context discussion for the encompassing district. Historic context for certain geographic areas are already developed by the city government, the State historic preservation office, or some federal agency. (NRB 15, p. 7)

\subsection{The Importance of the Historic Context Theme}

The happenings, events, and trends - the theme's ingredient-occurring in any geographic entity leave their imprint on the entity's buildings, structures, and landscapes, hence the significance of these spatial resources. In identifying a theme, the researcher can refer to the list of areas of significance used by the National Register. Examples of areas of significance include: agriculture, archaeology, art, commerce, communication, education, engineering, entertainment/recreation, health/medicine, industry, landscape architecture, literature, military, politics/government, religion, science, and transportation. Areas of significance for some buildings are shown in Table 2 together with corresponding applicable evaluation criteria and period of significance.

A historic geographic entity can have multiple areas of significance that support its historic context. Large entities tend to have multiple areas of significance that may apply to more than one historic context. The Birmingham Civil Rights, 1933-1979, Multiple Property Submission with a main historic context titled "The Civil Rights Movement in Birmingham, Alabama, 1933-1979” (NRHP, The Civil Rights) includes three constituent historic contexts supported by relevant areas of significance:

1. Institution Building for a Civil Rights Movement, 19331956

2. The Local Movement Becomes National: the Birmingham Civil Rights Movement, 1956-1964

3. Implementing the Civil Rights Movement in Birmingham, 1964-1979

It is obvious that the overarching theme in the main historic context is represented in the three sub-themes, one for each constituent historic context.

\begin{tabular}{|c|c|c|c|}
\hline Name & 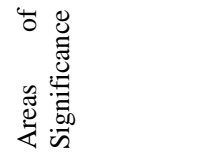 & 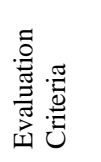 & 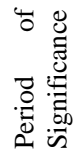 \\
\hline $\begin{array}{l}\text { Kirby Road School* } \\
\text { State: Ohio } \\
\text { County: Hamilton } \\
\text { Town: Cincinnati } \\
\text { Address: } 1710 \text { Bruce } \\
\text { Avenue }\end{array}$ & $\begin{array}{l}\text { Architecture, } \\
\text { Community } \\
\text { Development, } \\
\text { Education }\end{array}$ & $\overline{A A, C}$ & $\begin{array}{l}1910- \\
1963\end{array}$ \\
\hline $\begin{array}{ll}\text { St. Paul Union } \\
\text { Depot** } \\
\text { State: Minnesota } & \\
\text { County: Ramsey } & \\
\text { Town: St. Paul } & \\
\text { Address: } 214 \quad \text { East } \\
\text { Fourth Street } & \\
\end{array}$ & $\begin{array}{l}\text { transportation, } \\
\text { Commerce, } \\
\text { Industry, } \\
\text { Architecture, } \\
\text { Engineering }\end{array}$ & $\mathrm{A}, \mathrm{C}$ & $\begin{array}{l}1917- \\
1963\end{array}$ \\
\hline $\begin{array}{l}\text { Women's Rights } \\
\text { National Historical } \\
\text { Park*** } \\
\text { State: New York } \\
\text { County: Seneca } \\
\text { Town: Seneca Falls } \\
\text { and Waterloo }\end{array}$ & $\begin{array}{l}\text { Architecture, } \\
\text { Politics/Govern } \\
\text { ment, } \\
\text { Commerce, } \\
\text { Historic Non- } \\
\text { Aboriginal, } \\
\text { Social History }\end{array}$ & $\begin{array}{l}\text { A, B, } \\
\text { C, D }\end{array}$ & $\begin{array}{l}1917- \\
1963\end{array}$ \\
\hline $\begin{array}{l}\text { John W Jones } \\
\text { House**** } \\
\text { State: New York } \\
\text { County: Chemung } \\
\text { Town: Elmira } \\
\text { Address: } 1250 \text { Davis } \\
\text { Street }\end{array}$ & $\begin{array}{l}\text { Social History, } \\
\text { Ethnic Heritage }\end{array}$ & $\mathrm{B}, \mathrm{D}$ & $\begin{array}{l}1868- \\
1900\end{array}$ \\
\hline
\end{tabular}

Table 2. Areas of significance for some buildings Sources: * NRHP. NPS Form 10-900, Kirby High School. ** NRHP. NPS Form 10-900, St. Paul Union Depot; *** NRHP.

NPS Form 10-900, Women's Rights National; **** NPS Form 10-900, John W Jones House

\section{DEVELOPING THE HISTORIC CONTEXT: THE BUILDING ROLE}

\subsection{Meeting the Requirements for the Building Type}

Important historic events, trends, persons, and discoveries that merge into a unifying theme for a historic context occur in a spatial milieu of places and sites. Therefore, the types of properties associated with the historic context become the spatial representation of the themes, hence the importance of identifying the types of properties.

The building type discussion for individual properties such as a house or a bridge is, for obvious reasons, less involved than for areas with a bulk of properties such as a downtown district or a city. The latter most likely involves multiple types. For example, the context of "The Civil Rights Movement in Birmingham, Alabama, 19331979” includes a vast number of properties classified under Strategic Centers, Conflict Centers, Resolution Centers, Properties associated with prominent persons, and Properties associated with community groups, ethnic organizations, and institutions. The Strategic Centers class, for example, encompasses subgroups of churches, commercial buildings, public buildings, schools, and neighborhoods. 


\subsection{Meeting the Requirements for the Criteria for Evaluation.}

Now that the historic context is developed and property types are defined, the significance of any individual property (a building, a bridge, a historic park) can be evaluated in light of the historic contexts that the property is associated with. This is done by applying the four criteria for evaluation. "Within the scope of the historic context, the National Register Criteria define the kind of significance that the properties represent." (NRB 15, p. 11).

A property need to meet at least one criterion to acquire the quality of significance. To find out whether the property is significant, a set of evaluative steps are considered for each of the areas of criteria as shown below.

\section{Criterion A: Event or Trend}

- Compare the building specific history with the historic context with which it is associated

- Evaluate the degree in which the building is associated with an event or a pattern of events important in the associated historic context.

- Decide whether the association is strong enough to warrant declaring the quality of significance.

Criterion B: Eminent Individual/Group

- Determine the eminence of the individual in his or her field or profession; or the group in its area of endeavor

- Contrast the eminent life of the individual or group with the considered property under study

- Decide whether the association is strong enough to warrant declaring the quality of significance.

Criterion C: Genius Design \& Production

- Identify the physical characteristics of the property in its design, planning, and implementation

- Contrast the identified characteristics of the property with the characteristics of the reference in the historic context

- Decide whether the characteristics of the property are distinctive enough to warrant declaring the quality of significance.

Criterion D:

- Identify the spatial and physical characteristics of the property

- Contrast the obtained information with the existing information of the reference in the historic context

- Decide whether the obtained information has a potential to add new information to the history or prehistory to warrant declaring the quality of significance.

\subsection{Meeting the Requirements for the Building Integrity and Authenticity}

The physical and spatial conditions (features) the property possessed during the period of significance defines the property's historic identity and authenticity. If these features are still intact, then the building conditions are authentic, and accordingly the property holds the quality of integrity. In this case, integrity supports the significance of the property. If the original features are not intact, suffering from loss or change, then the building conditions are not authentic, and therefore the property might not maintain integrity. In this case, integrity does not support the significance of the property. In other words, "a property must not only be shown to be significant...but it also must have integrity" (NPR 15, p. 11). Integrity, a rather subjective concept, is substantiated or denied upon completion of an evaluation process structured around a number of attributes. The NRHP defines seven attributes of building integrity: a) location, b) design, c) setting, d) materials, e) workmanship, f) feeling, and, g) association (NPR 15, p. 11). If one or more of these attributes are altered, they could diminish the building significance. For example, moving a building from its original location, disturbs the relationship of the building and its historic association; changing a building space arrangement or façade fenestration alters the building design.

To find out whether the property has integrity, a set of evaluative steps are applied for each attribute of integrity (Figure 5):

- Establish the physical and spatial conditions of the property as they were during the period of significance.

- Check for the loss or change, if any, in the physical and spatial conditions as they stand at present.

- Determine whether the property maintains integrity in the attribute under consideration

The presence, or absence, of integrity will be based on holistic judgement factoring in the results of the evaluation completed for the seven parameters collectively. As the parameters do not typically bear equal weight on measuring the property's aggregate integrity, the weightiest parameters might decide the final judgement on whether the property possesses integrity.

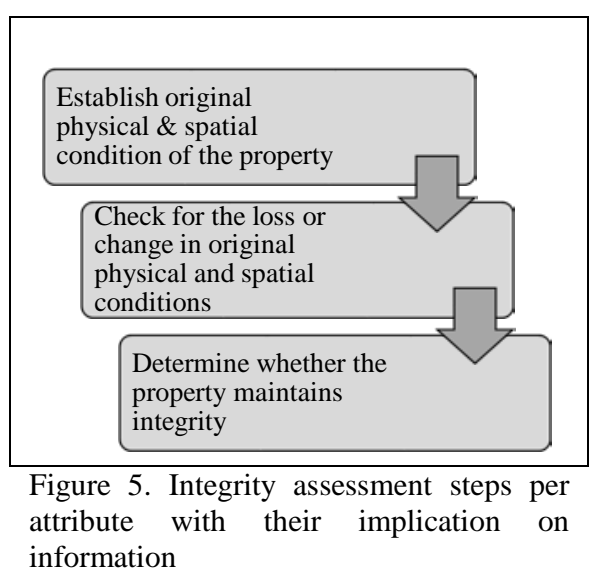
information 


\section{ATTRIBUTES OF INFORMATION FLOW}

\subsection{General}

In its final, refined form, the information handled in the historic context process transforms into a historic context statement. For the building type of properties, the statement is incorporated into the NPS Form 10-900, National Register of Historic Places Registration Form. In this National Register nomination form, the case for the building significance incorporates mainly in Section "8. Statement of Significance" and in Section "7. Description.”

The researcher provides additional information to populate subsidiary sections of the form. For example, Section 5, Classification addresses the identification of property ownership in terms of private or public. Section 6, Function or Use distinguishes between the historic use and the current use of the building.

\subsection{Scope of Information}

Guided by NPS Form 10-900, the researcher designs in advance the scope of information needed to drive the historic context process, and subsequently to adequately fill out the form. Adapted from the National Register's Researching a Historic Property (NRHP, NRB 39, p. 3), the following represents the salient information items to be addressed:

- $\quad$ The building name during the period of significance

- The building date of construction

- $\quad$ The date the building took the present form

- The building historic characteristics

- Any changes made to the building spaces, materials, and features

- The effect of the changes on the historic integrity

- Present conditions of the building including the exterior, the interior, the immediate grounds, and context

- $\quad$ The historic use of the building

- $\quad$ The present use of the building

- The owners and users of the building historically

- The owners and user of the building presently

- The owners and users of the building who contributed to history

- Important events or reoccurring activities associated with the building

- Important figures associated with the building

- Thematic areas of significance the building falls into.

- The National Register criteria that apply to the building

- The building relationship to the larger context history

- The building ability to illustrate themes or trends important to the history of its community, State, or nation?

- Building size, location, and boundaries

\subsection{Sources of Information}

The National Register's Bulletin Researching a Historic Property identifies twenty four broad categories of information sources with a number of member sources under each category (NRHP, NRB 39, p.5). Architectural/construction drawings, architectural journals, and genealogical records are three examples of categories of information sources. These sources are allencompassing, meant to support the National Register nominations for any class of properties including buildings, sites, structures, districts, and objects. Because each category of sources tend to yield information that supports specific aspect or aspects of the nomination form, using these sources in building nominations invites the researcher's discretion in planning the access to these sources. For example, the awareness that the architectural/construction drawings category and the building permits category can yield information important to developing the integrity discussion would help plan gathering information from these two source categories.

\subsection{National Register Listing Process}

The listing process (NRHP, Program Fundamentals) start with submitting the nomination by the property owner, a historic society, or other party to the State Historic Preservation Office, SHPO (Figure 5). The SHPO solicits public comments and reviews the nomination. Subsequently, after the nomination is reviewed by the state's National Register Review Board, the SHPO submits completed and certified nomination to the National Park Service for listing consideration by the Keeper of the National Register. The reviews of the nomination by different parties throughout the listing process is regulated by a time limit at each party stop.

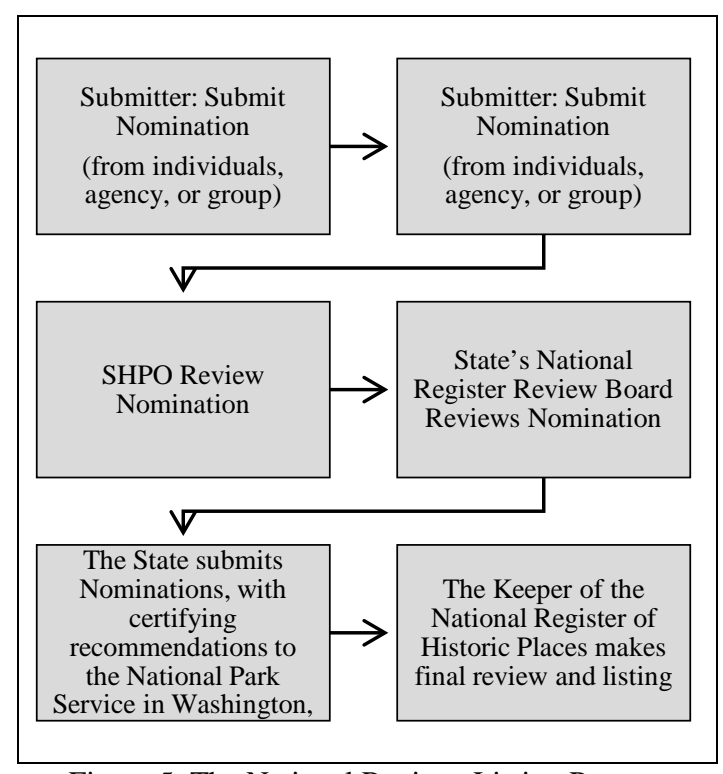

Figure 5. The National Register Listing Process 


\section{CONCLUSIONS}

Conclusions have emerged in five areas.

\subsection{Information Settings}

Approaching information gathered, processed, and presented in the global course of a rehabilitation project in terms of settings enhances our understanding of the information flow in the process. The three-information setting proposal presents an opportunity for useful engagement by the professionals involved in these related information settings.

\subsection{Realm of Research}

The first information setting singled out for this study "the setting for information associated with authenticating the building significance," falls squarely in the realm of research. Research and writing skills pertinent to configuring and developing historic contexts and to completing National Register nomination forms are indispensable.

\subsection{Usefulness of the Historic Context}

With its time, place, and theme elements, the historic context is a useful construct for assessing the significance of historic properties and subsequently for listing them on the National Register. While the time and place define respectively the chronological and geographic boundaries of the historic context, the theme, permeated with cultural meanings, represents the raison d'être for the historic context all together.

\subsection{The Building Physical and Spatial Conditions}

While the historic context construct is laden with cultural references, it capitalizes on the physical and spatial conditions of the building —as it was and as it is now - to develop, through the historic integrity and authenticity, a convincing case for the worth of the edifice, and subsequently for recognizing it through the NRHP listing process.

\subsection{The Flow of Information}

The information need to be acquired and processed in the course of configuring the building historic context and in developing the historic context flow in parallel with the processes for fulfilling these two aims of the study. The flow of information smoothens with the researcher's knowledge and dexterity: a) in configuring and developing historic contexts, b) in the different attributes of information including the scope, sources, and documentation of information in shape of a historic context statement, and c) in the process of the National Register listing.

\section{REFERENCES}

The source references below reflect the relevance of the National Register of Historic Places to the topic of this study.

National Register of Historic Places. The Civil Rights Movement in Birmingham, Alabama, 1933-1979 https://www.nps.gov/nr/publications/sample_nominations/Civil RightsBirminghamMPS.pdf (13 June 2017).

National Register of Historic Places, 1995. National Register Bulletin 15: How to Apply the National Register Criteria for Evaluation

https://www.nps.gov/nr/publications/bulletins/pdfs/nrb15.pdf (10 June 15, 2017)

NRB 15, How to Define the Type of Significance of a Property

NRB 15, How to Evaluate the Integrity of a Property NRB 15. How to Evaluate a Property within its Historic Context

NRB 15. National Register Criteria for Evaluation NRB 15. Understanding Historic Context

National Register of Historic Places, 1998. National Register Bulletin 39: Researching a Historic Property, p. 3 https://www.nps.gov/nr/publications/bulletins/nrb39/ (11 June 2017).

National Register of Historic Places. National Register of Historic Places Program: Fundamentals. https://www.nps.gov/nr/national_register_fundamentals.htm (12 June 2017).

The following identify the source references for Table 2.

*NRHP. NPS Form 10-900, Kirby High School. https://www.nps.gov/nr/feature/places/pdfs/13000681.pdf (5 June 2017).

**NRHP. NPS Form 10-900, St. Paul Union Depot. https://www.nps.gov/nr/feature/places/pdfs/14000039.pdf （7 June 2017).

***NRHP. Women's Rights National Historical Park. https://www.nps.gov/nr/feature/weekly_features/2012/Womens RightsNHPBI.pdf (13 June 2017).

***NRHP. NPS Form 10-900, John W Jones House. https://www.nps.gov/nr/publications/sample_nominations/John WHonesHouse.pdf (13 June 2017). 